\title{
'Lavender Lady', Flowering Ornamental Cuphea glutinosa
}

\section{Casimir A. Jaworski}

Agricultural Research Service, U.S. Department of Agriculture, Tifton, GA 31793

\section{Sharad C. Phatak \\ University of Georgia, Tifton, GA 31793}

Additional index words. ground cover, landscape plant

Cuphea, a genus in the Lythraceae, includes $\approx 260$ species and is native mostly from Mexico through Brazil (Graham and Kleiman, 1985). C. glutinosa (Chain. \& Schldl.) is a native of Brazil (Graham et al., 1981). The primary interest in Cuphea spp. is for its seed as a source of medium chain triglycerides; however, landscape and ornamental use is an alternative for some Cuphea spp. (Jaworski and Phatak, 1990; Pottberg, 1984; Thompson et al., 1987).

Cuphea glutinosa selection 'Lavender Lady' has potential use as a landscape and ornamental plant for the southeastern United States. This plant is adapted only to full sun

Received for publication 2 Apr. 1990. The cost of publishing this paper was defrayed in part by the payment of page charges. Under postal regulations, this paper therefore must be hereby marked advertisement solely to indicate this fact. and has winter hardiness in U.S. Dept. of Agriculture Plant Hardiness Zone 8A (Jaworski and Phatak, 1990). The plants produce a large mass of purple flowers from early April until mid-November. Natural propagation is by rooting of stoloniferous shoots, by underground stolons, and by seeds.

\section{Origin}

'Lavender Lady' was selected from 25 plants remaining out of 220 C. glutinosa plants grown on Dothan loamy sand (fine loamy, siliceous, thermic, Plinthic Kandiudults) that survived Winter 1986-87 in Tifton, Ga. These 220 plants were produced from seeds of Arizona accession numbers A 0015, A 0172, A 0175, and A 0247, now located at Ames, Iowa. 'Lavender Lady' originated from A 0172 and was assigned Georgia number GA 21.

\section{Description}

Selection of 'Lavender Lady' was based on overwintering, superior ground cover (50$\mathrm{cm}$-diam circle within 100 days of planting), short height (12 cm 1st year), six-petal flowers, and superior number of flowers (up to 27 flowers per $100 \mathrm{~cm}^{2}$ ) and attractive color (Fig. 1) (Jaworski and Phatak, 1990). The maximum leaf size for 'Lavender Lady' was $2.5 \times 1.4 \mathrm{~cm}$.

Flowering in the field was from early April until the first autumn freeze, about mid-November in Tifton, Ga. Flowering was continuous through the year in the hanging baskets and in the pots under greenhouse conditions. The maximum flower petal spread was 1.6 $\times 1.8 \mathrm{~cm}$, the maximum size of the four ventral petals was $0.8 \times 0.3 \mathrm{~cm}$, and the maximum size of the two dorsal petals was $0.8 \times 0.5 \mathrm{~cm}$. The ventral flower petals are purple violet (81C) (Royal Horticultural Sot., 1966) and dorsal petals are purple violet (80A). The flower petal veins are purple (77A). The leaves are very small at the base of the plant, reach maximum size before flowering, and are much smaller in the flowering portion of the shoot. 'Lavender Lady' leaves were an attractive green (137A). Stems and leaves $>5 \mathrm{~cm}$ above the ground were usually killed by cold weather, while the stems and leaves next to the ground and which completely cover the soil remained attractive and green throughout the winter. The lowest temperature in the three winters of 1987 through 1989 was -11C.

The adaptation of 'Lavender Lady' as per-

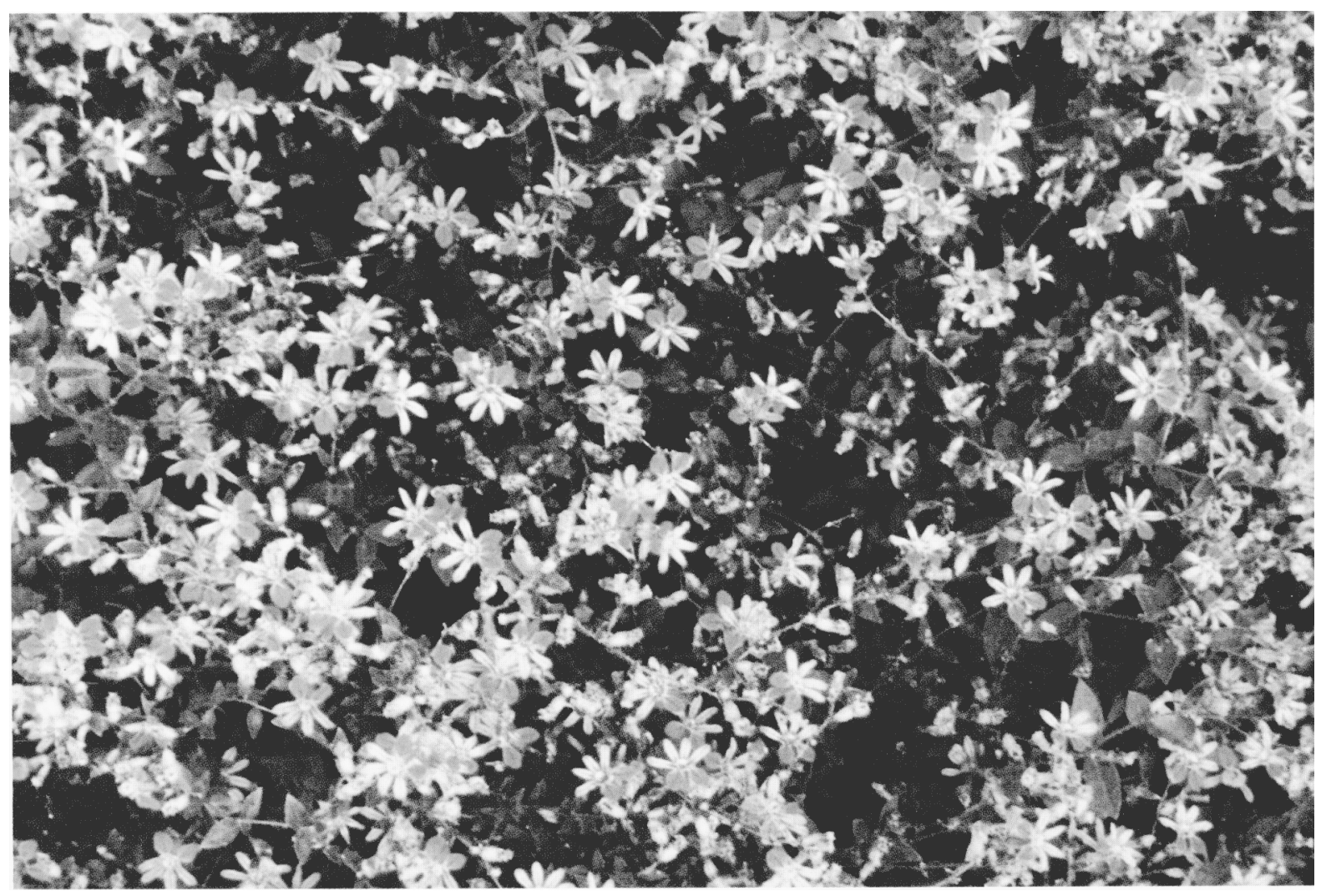

Fig. 1. Cuphea glutinosa 'Lavender Lady'. 
manent plantings in commercial and residential landscape in regions colder than Tifton has yet to be evaluated. 'Lavender Lady' proliferate into a dense mat of rooted shoots that completely cover the ground, and this characteristic may add value for erosion control and beautification along highways and as potted plants.

\section{Availability}

Information for propagation of 'Lavender Lady' can be obtained by writing S.C.P. Horticulture Dept., CPES, P.O. Box 748,
Tifton, GA 31793.

\section{Literature Cited}

Graham, S.A. and R. Kleiman. 1985. Fatty acid composition in cuphea seed oils from Brazil and Nicaragua. J. Amer. Oil Chem. Soc. 62:81-82.

Graham, S.A., F. Hirsinger, and G. Robbelen. 1981. Fatty acids of cuphea (Lythraceae) seed lipids and their systematic significance. Amer. J. Bot. 68:908-917.

Jaworski, C.A. and S.C. Phatak. 1990. Cuphea glutinosa selections for flowering ornamental ground cover in southeast United States, p. 467469. In: J.E. Simon and J. Janick(eds.). Ad- vances in new crops. Proc. 1st Nat. Symp. New Crops: Res., Devel., Econ. Timber Press, Portland, Ore.

Pottberg, C.F. 1984. Cuphea plant table top bonsai [Cuphea hyssopifolia, dwarf size, internodal dwarfing, a spreading growth form and profuse, substantially constant blooming] .3 Apr. 1984. U.S. Plant Patent 5214.

Royal Horticultural Society. 1966. Royal Horticultural Society colour chart. Royal Hort. Soc., London.

Thompson, A.E., D.T. Ray, and M.S. Rob. 1987. Evaluation of Cuphea procumbens $\times$ C. llavea hybrids as new floral and bedding plants. HortScience 22:1142-1143. (Abstr.) 